Tadeusz Gadacz

\title{
O wdzięczności
}

Wdzięczność i gotowość. Otrzymałeś wszystko - za nic. Nie wahaj się, gdy trzeba dać to, co przecież jest niczym - za wszystko.

Dag Hammarskjöld, Drogowskazy, s. 105

Sokrates zaliczył wdzięczność do niepisanych praw, które obowiązują wszystkich wobec bogów. Hipokrates nazwał ją w swym języku ojczystym euharistia. Wdzięczność, jedna z piękniejszych cnót, która czyniącym ją dodaje wdzięku. Cyceron, pisząc w De officiis o obowiązku wdzięczności: nullum enim officium referende gratia magis necessarium est ${ }^{1}$, użył określenia gratia, które oznacza przychylność, łaskę, radość, wdzięczność i wskazuje na inne słowo: gratuitus, czyli bezpłatny.

Jak bardzo oddaleni jesteśmy od rozumienia wdzięczności przez Hipokratesa i Cycerona, kiedy myślimy o niej tak, jak pozwalają nam na to powierzchowne zdarzenia życia. Przychodzą nam wówczas na myśl negatywne, a dla niektórych być może „pozytywne” skojarzenia związane z umiejętnością tzw. „radzenia sobie” w codzienności. Ludzie wciąż załatwiają różne sprawy, interesy, obiecując tym, u których szukają poparcia, swoją wdzięczność. Mają na myśli łapówkę, materialną gratyfikację czy też zwyczajną odpłatę w formie własnych znajomości, którymi gotowi są dzielić się ze swymi „dobroczyńcami”.

${ }^{1}$ Cycero n, De officiis, I, 15, 47. 
Mówią wówczas: „potrafię być wdzięczny”, „umiem się odwdzięczyć”. Wdzięczność zostaje w ten sposób sprowadzona do ekonomicznej rachunkowości, która pojawia się zarówno po stronie „winien”, gdy myślimy o tych, którym coś jesteśmy dłużni, jak i „ma”, gdy z kolei rachujemy naszych dłużników.

Czasami rodzice skarżą się na niewdzięczność swoich dzieci. „Poświęciliśmy im wiele sił i troski, nieprzespanych nocy - mówią. Ofiarowaliśmy im wiele, a dzisiaj zostaliśmy opuszczeni. Cóż za czarna niewdzięczność". Taka skarga jest często skutkiem, choć oczywiście nie zawsze, traktowania swoich dzieci jak bankowego konta, w które składa się oszczędności, by na starość móc żyć z odsetek. Tymczasem konto okazuje się puste. Ten, kto ofiarowuje coś innym, licząc na odpłatę, może się szybko rozczarować. Dobroczyńca nie powinien liczyć na żadną wdzięczność, a wręcz nawet jej nie pragnąć. Wdzięczność nie pozostaje bowiem w takim stosunku do daru, jak księgowe konta: „winien” i „ma”. Dobroczyńca, który liczy na wdzięczność, przestaje być bezinteresowny, a dar jest zawsze bezinteresowny. Inaczej nie jest już darem. Podobnie też bezinteresowną jest odpowiedź na dar, czyli wdzięczność. Dar i wdzięczność nie spotykają się więc ze sobą tak, jak dług i jego spłata.

By „zasłużyć” na wdzięczność, nie należy tylko obdarowywać, ale kochać. Dar bez miłości staje się właśnie ekonomiczną inwestycją. , Jeśli chcesz zasłużyć na wdzięczność obligowanych, powinieneś nie tylko obdarowywać ich dobrodziejstwami, ale także kochać"2, pisał L. A. Seneka. W jednym tylko trudno zgodzić się z nim. Na wdzięczność się nie zasługuje. Wdzięczność jest także darmowym, bezinteresownym darem. Choć więc czasami mówimy przenośnie o ,zasługiwaniu na” wdzięczność, to trzeba się radować, gdy dobroczyńcę spotyka prawdziwa wdzięczność, ale nie należy nigdy mieć pretensji, że się na nią zasłużyło.

Choć na wdzięczność się nie zasługuje, to istnieją jednak pewne sytuacje życiowe czy też międzyludzkie relacje, które ze swojej natury wydają się domagać wdzięczności. Myślimy np. o stosunku dzieci do rodziców, uczniów do wychowawców czy pacjentów do lekarzy. Nie znaczy to oczywiście, że wszyscy rodzice, nauczyciele i lekarze w równym stopniu zasługują na wdzięczność. Niemniej jednak właśnie tu wdzięcz-

${ }^{2}$ L. A. S e n e k a, Myśli, przeł. S. Stabryła, Kraków 1987, s. 265. 
ność jest oczekiwana i spodziewana. Także w podobnych sytuacjach mówimy o „obowiązku” wdzięczności. Dzieci powinny być wdzięczne rodzicom, uczniowie wychowawcom, pacjenci swoim lekarzom. Jednak tak, jak nie można mieć pretensji, że się zasłużyło na wdzięczność, a nie otrzymuje się jej, tak też nie ma przymusu wdzięczności. Czymś innym bowiem jest obowiązek troski o zdrowie rodziców i o ich warunki życia, a czymś innym wdzięczność, która jest jednym z najbardziej dobrowolnych darów.

Wdzięczność jest pewną odmianą miłości, przychylnością, łaskawością wobec tych, którzy uczynili nam coś dobrego, a nie musieli wcale tego uczynić. Kiedy nie mając takiego obowiązku, bezinteresownie wyciągnęli do nas rękę, udzielili pomocy. Powinniśmy być im wdzięczni nie dlatego, by móc znowu liczyć na ich dobroć, ale dlatego, że należy być wdzięcznym. Czyn wdzięczności jest piękny sam w sobie, gdyż jest bezinteresowny. Najpełniej da się to dostrzec wówczas, gdy jesteśmy wdzięczni wiedząc, że nie możemy już na nic liczyć. „Niewielu zachowuje wdzięczność po otrzymaniu dobrodziejstwa. Większość dopóty pamięta o darach, dopóki z nich korzysta", pisał Seneka. Dlatego wdzięczność jest wówczas piękniejsza i czystsza, gdy skierowana jest do tych, którzy kiedyś okazywali nam dobrodziejstwa, a teraz sami ich potrzebują. Wdzięczność jest więc bezinteresowna. Przysparza więcej dobra temu, który jest wdzięczny, niż korzyści temu, komu wdzięczność się okazuje.

Wdzięczność jest dziedziną pamięci. By być wdzięcznym nie tylko należy pamiętać o dobroczyńcach, lecz także pamiętać o nich szczególnie wtedy, gdy nie możemy już niczego spodziewać się od nich. Lecz wdzięczność jest też w tym znaczeniu dziedziną pamięci, że ten, kto zapomina o swych dobroczyńcach, odwraca się od swej własnej historii i traci przeszłość. „Niewdzięczność zaczyna się od zapomnienia - pisał D. Bonhoeffer - z zapomnienia wynika obojętność, z obojętności - niezadowolenie, z niezadowolenia - rozpacz, z rozpaczy - przekleństwo"4.

Do wdzięczności zdolni są ludzie zacni i szlachetni. Dusze niskie i niewolnicze są albo niewdzięczne, albo też wdzięczne przesadnie.

3 Tamże, s. 259.

${ }^{4}$ D. B o n h o e ffe r, Wybór pism, przeł. A. Morawska, Warszawa 1970, s. 129-131. 
Różne mogą być źródła niewdzięczności. Niektórzy nie chcą w ogóle przyjmować żadnych darów, ponieważ duma albo lęk nie pozwala im zaciagać jakichkolwiek zobowiązań. Jeśli czują się zmuszeni je przyjąć, usiłują w pośpiechu spłacić dług wdzięczności, aby nie czuć zbyt długo zależności od innych. „Duszy szlachetnej ciąży myśl, że ktoś się jej czuje obowiązany do podzięki, gminnej, że one komuś", pisał Friedrich Nietzsche ${ }^{5}$. Tylko ci umieją być wdzięczni, którzy zdolni są do przyjmowania darów z pełną szczerością.

Niewdzięczni są także ludzie pretensjonalni, którym wydaje się, że wszystko, co otrzymują, jest im należne. W ich życiu nie ma miejsca na dar, a przez to też i na wdzięczność.

Niewdzięcznymi bywają często ci, którym darowano wiele, gdyż samo przyjęcie wielkiego daru związane jest u obdarowanego z tak głębokim przeżyciem, że brak mu odwagi na wdzięczność. „Ten, kto darował coś wielkiego, pisał F. Nietzsche, nie znajduje wdzięczności; bowiem obdarowany już przez to samo, że dar przyjął, za wielkie brzemię wziął na siebie" . Dlatego dobroczyńców spotyka nie tylko brak wdzięczności, ale także niejednokrotnie nienawiść. „Prawie wszyscy lubią się uiszczać z drobnych zobowiązań, wielu jest wdzięcznych za średnie; ale nie ma prawie nikogo, kto by nie odpłacał niewdzięcznością wielkich"7. Podobny sens wyraża przysłowie: ,za złe czyny karzą po śmierci, a za dobre jeszcze za życia”. Dlatego może łatwiej rozumiemy pytanie postawione przez jednego z bohaterów Fiodora Dostojewskiego: „Dlaczego mnie tak nienawidzisz? Przecież nie uczyniłem ci niczego dobrego?”

Przyczyną niewdzięczności może być także utylitarystyczne podejście do życia. Ludzie, którzy kierują się korzyścią, boją się wydatków, ryzyka. Potrafią tylko liczyć.

Powodem niewdzięczności bywa także nieumiejętność odróżniania tego, co jest czyimś obowiązkiem od tego, co przekracza znacznie ramy tego obowiązku. W tym, co dotyczy opieki rodziców nad dziećmi, troski wychowawców czy lekarzy, trudno wyznaczyć granicę między obowiąz-

${ }^{5}$ F. N i e t z s c h e, Ludzkie, arcyludzkie, przeł. K. Drzewiecki, Warszawa-Kraków 1910, s. 299.

6 Tamże, s. 297.

${ }^{7}$ La Rochefouca uld, Maksymy $i$ rozważania moralne, przeł. T. Żeleński-Boy, Warszawa 1977, s. 76. 
kiem a tym, co nim już nie jest. Niektórzy więc sądzą, że jakieś szczególne, wyjątkowe poświęcenie należało do czyjegoś obowiązku i dlatego nie są przekonani, że powinni za to być wdzięczni. Tak jednak sądzą najczęściej ludzie pretensjonalni, którym się wydaje, że wszystko im się należy.

Źródłem niewdzięczności może być też źle rozumiana miłość i dobroć. Czasami rodzice czy wychowawcy są przesadnie troskliwi i pragną wciąż, na różne sposoby, wyrażać swoją miłość i dobroć. Jednocześnie dziwią się, że ci, którym tę dobroć okazują, nie są im wdzięczni. Tak jednak ,przyduszają" swoją miłością, że pozbawiają ich wszelkiej samodzielności, także możliwości okazania tego, jak bardzo im są „wdzięczni”.

Niewdzięczność wypływa też z podłości. Są ludzie, którzy szukają pomocy innych, a otrzymawszy ją - nienawidzą ich, ponieważ wyobrażają sobie, że wszyscy ludzie są tacy sami jak oni. Myślą, że wyprowadzili ich w pole, albowiem - według ich przekonania - nikt nie czyni niczego dobrego bez nadziei nagrody.

Przyczyną niewdzięczności może być wreszcie wzbudzony w obdarowanym wstyd lub niecierpliwość. Trudno liczyć na wdzięczność tam, gdzie poniża się obdarowanego, okazuje mu swoją wyższość, budzi w nim wstyd lub zbyt długo każe czekać w przedpokoju łaski.

Czasami jednak trudniejszą do zniesienia od niewdzięczności jest przesadna wdzięczność. Jest ona bardzo kłopotliwa. Nie musi wcale kierować się nadzieją przyszłych korzyści. Bywa „bezinteresowna”. „Są dusze niewolnicze - pisał Nietzsche - które tak daleko posuwają uznanie za wyświadczone dobrodziejstwa, iż sznurem wdzięczności same się duszą" ".

Do wdzięczności nie wystarczy jednak tylko duchowe usposobienie. Co prawda ważna jest i przychylność, którą nosimy w sercu dla naszych dobroczyńców. Trzeba jednak czegoś więcej, wyrazów wdzięczności. Czymś innym więc niż wdzięczność jedynie odczuwana jest wdzięczność okazywana. O okazywaniu wdzięczności świadczą drobne wyrazy pamięci: list, kartka z pozdrowieniami czy życzeniami, telefon, podarunek, odwiedziny, wszelka możliwa pomoc.

Czy większość ludzi jest wdzięcznych, czy też nie? Pesymiści i optymiści różnią się tu dość znacznie. A. Schweitzer sądził, że większość odczuwa wdzięczność, zbyt mało jednak ją okazuje.

${ }^{8}$ F. N i et z s c h e, $d z$. cyt., s. 299. 
Kiedy w perspektywie lat spoglądam na swoją młodość - pisał - wzrusza mnie myśl, jak wielu ludziom winien jestem wdzięczność za to, co mi dali lub czym dla mnie byli. Zarazem jednak ze smutkiem uświadamiam sobie, jak niewiele tej wdzięczności w istocie okazałem owym ludziom, gdy byłem młody. Wielu z nich rozstało się z życiem, zanim zdołałem wyrazić, jakie znaczenie miała dla mnie okazana mi przez nich dobroć i wyrozumiałość. Nieraz nad grobami głęboko poruszony wypowiadałem w duszy słowa, które moje usta niegdyś winny były przekazać żywym [...].

Biorąc pod uwagę swoje własne przeżycia, nie sądzę, by w świecie było tak wiele niewdzięczności, jak się zazwyczaj twierdzi. Nigdy nie mogłem przyjąć takiej interpretacji opowieści o dziesięciu trędowatych, zgodnie z którą tylko jeden z nich poczuwał się do wdzięczności. Sądzę, że wdzięczni byli wszyscy. Ale dziewięciu z nich udało się najpierw do domu, by szybko pozdrowić bliskich i rozejrzeć się w swoich sprawach, odkładając na potem pójście do Jezusa z podziękowaniem. Nie doszło do tego, gdyż sprawy domowe zatrzymały ich, a w tym czasie Jezus zmarł. Jeden natomiast miał dar kierowania się bezpośrednim odczuciem. Odszukał więc zaraz tego, który mu pomógł i swoją wdzięcznością dodał mu otuchy.

Wszyscy winniśmy się starać o bezpośredniość, o to, by wdzięczność nieokazywana stała się okazywaną. Wtedy będzie więcej w świecie słońca i więcej energii, aby czynić dobro'.

${ }^{9}$ A. S c hwe it ze r, Człowiek wobec czlowieka, [w:] I. La z a r i-P a w ł ow s k a, Schweitzer, Warszawa 1976, s. 75-76. 